\title{
Brief review of operation of anaerobic wastewater treatment with membrane bioreactors
}

\author{
Zbigniew Mucha ${ }^{1, *}$,Wtodzimierz Wójcik ${ }^{2}$, and Michał Polus ${ }^{1}$ \\ ${ }^{1}$ Faculty of Environmental Engineering, Cracow University of Technology, Warszawska St. 24, 31-155, Cracow, Poland \\ 2 Department of Environmental Engineering, Krosno State College, Rynek 1, 38-400, Krosno, Poland
}

\begin{abstract}
In recent years, anaerobic membrane bioreactor (AnMBR) technology has been considered as a very appealing alternative for wastewater treatment due to its significant advantages over conventional anaerobic treatment and aerobic membrane bioreactor (MBR) technology. The paper provides an overview of the current status of the anaerobic membrane bioreactor technology with a special emphasis on its performance and drawbacks when applied for domestic and municipal wastewater treatment. According to the reported data, the renewable energy produced at the plants (i.e. from methane) covered the energy demand for membrane filtration while the excess energy can be further utilized. Anaerobic membrane bioreactors are an attractive technology that needs further research efforts and applications at an industrial scale.
\end{abstract}

\section{Introduction}

Implementation of the increasingly stringent requirements, related to the quality of effluents discharged into receiving water, calls for use of new technological solutions that would be more efficient than a conventional wastewater treatment.

Membrane separation techniques have found a number of practical applications in wastewater treatment. They have been used for treatment of both industrial and municipal sewage [1-4]. A decline in membrane investment costs, observed in recent years, contributed strongly to an increase of the number of devices sold.

Membrane reactors, as a concept, originated from development and modernization of activated sludge methods. They were membrane bioreactors (MBR) utilized usually in aerobic wastewater treatment.

The successful application of membrane separation technology for wastewater treatment resulted in attempts to expand their use also for anaerobic treatment. In addition, lower costs of membrane modules also favor their use for anaerobic processes in Anaerobic Membrane Bioreactors (AnMBR). Though these technologies are so far at a preliminary phase of implementation (laboratory or pilot scale operations) some authors [5] suggest that the AnMBR is a promising and constantly evolving technology. However, there is no comprehensive knowledge that would allow for its widespread use, compared to aerobic MBR technologies.

As it has been well known, anaerobic organisms grow more slowly than aerobic organisms. Therefore, anaerobic treatment requires a long sludge age (SRT) to obtain high process efficiency. Conventional anaerobic reactors meet all these requirements by using granule or biomass - based technologies. Due to a long solid retention time conventional anaerobic reactors can also accept high pollution loads.

The use of membrane separation techniques in anaerobic processes helps to obtain the required biomass retention time and serves as a unconventional solution in which AnMBRs can be operated at a longer SRT. Use of the membrane modules in anaerobic treatment retains virtually all microorganisms within the reactor and provides conditions for their complete growth, thereby increasing the process efficiency. This is important because anaerobic digestion is a complex process, involving bacteria of a different growth rate, so the process SRT may vary from several hours to even several days. The bacteria grow faster in aerobic conditions, and their growth is adjusted to a shorter SRT while aerobic reactors can be efficiently operated at lower temperatures. Thus, the temperature is another factor limiting the widespread implementation of AnMBR systems apart from fouling that appears to be more severe in AnMBRs then in aerobic MBRs [5].

As is has been well known, biogas production is one of the main advantages of anaerobic processes; a biogas volume depends on the composition of wastewater treated by AnMBRs and it is not always sufficient to cover the heating requirements, especially in regions with a cold climate.

Fig. 1 presents basic layouts of AnMBRs with external (side-stream) membrane modules (a) [6] and submerged membranes (b) [7].

Polymeric membranes are the most widely used in AnMBRs due to their low manufacturing costs [5] and some experience in their operation. Coupling ceramic

\footnotetext{
*Corresponding author: zmucha@vistula.wis.pk.edu.pl, mpolus@vistula.wis.pk.edu.pl
} 
membranes with AnMBRs offers a great potential as ceramic membranes are resistant to corrosive chemicals e.g. dry cleaning reagents, and harsh environmental conditions [8].

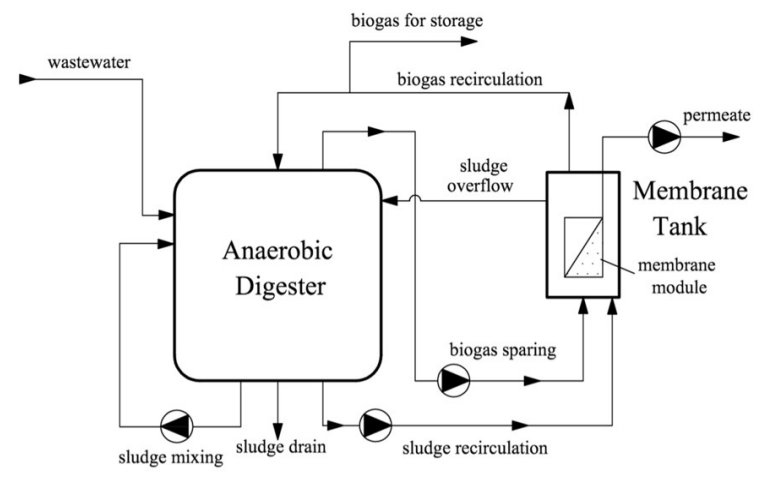

a)

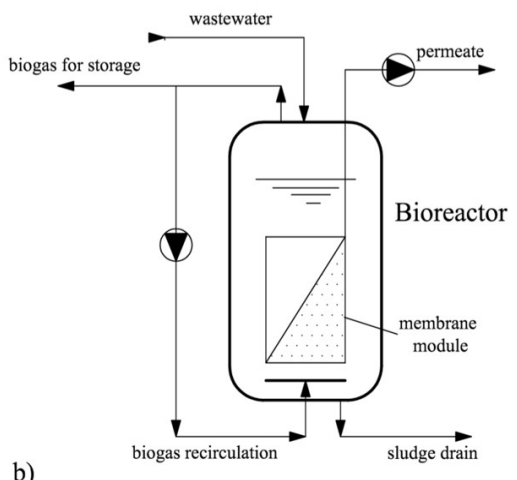

Fig. 1. AnMBRs with different membrane modules $[6,7]$.

\section{Wastewater treatment}

The available literature shows that AnMBRs have been tested in treatment of industrial, domestic and municipal wastewater. A comparable effluent quality (defined as COD) was obtained in AnMBR and MBR reactors of a similar size for domestic wastewater. However, operating costs were different since AnMBRs did not need aeration [5]. Attention was also paid to the greater sensitivity of AnMBRs to possible toxic discharges. At such situation, a detailed wastewater analysis may be required and a possible removal of a toxic compound upstream from AnMBRs should be assured.

The study on AnMBRs covered a wide range of technological parameters. Hydraulic retention time (HRT) varied within the range from a few hours up to 20 days while SRT varied from a few days to about a year [9-13]. All that did not cause significant changes in sludge properties. The sustainable membrane flux applied in most AnMBR studies [14] was below 15 LMH. On the other hand, this parameter for aerobic MBRs ranged from 25 to $140 \mathrm{LMH}$. and from 3.7 to 85 $\mathrm{LMH}$ for external and submerged configurations, respectively.
COD removal efficiencies varied from $76 \%$ to $99 \%$ depending on the wastewater composition [15]. A COD removal will decrease with an increase of a membrane pore size; typical pore sizes were in the range of 0.01 $0.45 \mu \mathrm{m}[14]$. Both overall hydrolysis rates and microbial growth decrease with temperature in AnMBRs and therefore a longer SRTs are required to compensate for low activity of microorganisms at low temperatures.

Initially, most of the investigated processes was carried out at $35^{\circ} \mathrm{C}$, which corresponds to mesophilic conditions, although some studies have also focused on thermophilic conditions $\left(55^{\circ} \mathrm{C}\right)$ and lower temperatures (around $20^{\circ} \mathrm{C}$ ). The process temperature effects COD removal efficiency [5]; at higher temperatures better removal efficiency of COD was achieved. The studies conducted in 2008 [16] showed that a COD removal rate in thermophilic conditions was $14 \mathrm{~g} \mathrm{COD} / 1 \cdot \mathrm{d}$, while in mesophilic conditions it did not exceed $10 \mathrm{~g} \mathrm{COD} / 1 \cdot \mathrm{d}$.

During AnMBR pilot studies [16] conducted on municipal wastewater at $\mathrm{STR}=28.6 \mathrm{~d}, \mathrm{HRT}=12,1 \mathrm{~h}$ and $\mathrm{T}=17.1^{\circ} \mathrm{C}$ a sludge yield of $0.46 \mathrm{~kg} \mathrm{DM} / \mathrm{kg}$ COD rem. and the COD removal efficiency of $94 \%$ were observed. The membranes permeability was about $100 \mathrm{LMH} / \mathrm{bar}$ during the process.

The AnMBR research conducted in a lab scale [17] in psychrophilic conditions $\left(15^{\circ} \mathrm{C}\right)$ on synthetic domestic wastewater treated with microfiltration membrane plates (pore size of $0.2 \mu \mathrm{m}$ ) showed the average COD and BOD removals as $92 \%$ and $92 \%$, respectively (effluent BOD $=$ $18 \mathrm{mg} / \mathrm{l})$. In the studies with real domestic wastewater a COD removal efficiency was lower (69\%).

During the 351 days of process operation, the amount of sludge in the reactor increased from 6000 to 10600 $\mathrm{mg} \mathrm{VSS} / 1$, which corresponded to the sludge yield of less than $0.10 \mathrm{~g} \mathrm{VSS} / \mathrm{g}$ COD rem. As it was expected, nutrients were not removed at a satisfactory level during the process so it may be an option when there is no need for nutrients removal. Otherwise, further wastewater treatment is recommended.

Other studies have been done in a lab scale installation with submerged ceramic membranes. The study was performed on domestic wastewater and the process parameters were; HRT $=7.5 \mathrm{~h}, \quad \mathrm{SRT}=60 \mathrm{~d}$, temperature $25-30^{\circ} \mathrm{C}$. The COD removal was $86-88 \%$ $[8]$.

A comprehensive study on the AnMBR process design parameters was carried out at a pilot scale installation [18]. Municipal wastewater was treated at ambient temperature of $15-30^{\circ} \mathrm{C}$. Each membrane tank featured an ultrafiltration HF submerged membrane with a pore size of $0.05 \mu \mathrm{m}$. The results of the study were presented in Table 1.

Interesting results were received during pilot-scale laboratory experiments in which AnMBR was operated with very short HRT $-2.2 \mathrm{~h}$ and the membrane flux maintained at $6 \mathrm{l} /\left(\mathrm{m}^{2} \mathrm{~h}\right)$. Operation of such systems during 340 days showed COD removal around $87 \%$ [13]. The membrane had mean pore size $0.2 \mu \mathrm{m}$. However, raw municipal wastewater discharged to the reactor was pretreated with $0.18-\mathrm{mm}$ micromesh screen. 


\section{Energy recovery}

Energy recovery is an important element of AnMBR technology. Energy is produced from biogas obtained as a result of COD decomposition. It has been found that up to $98 \%$ of COD removed from wastewater can be converted into biogas, which consists of methane (70-90\%), carbon dioxide (3-15\%) and nitrogen $(0-15 \%)$ $[5,13,14,19,20]$. The methane rich biogas can be used for digester heating, electricity generation or even recycled for fuel production. It was reported that 2.02 $\mathrm{kWh} / \mathrm{kg}$ COD rem. can be produced during treatment of synthetic wastewater in an AnMBR, which is approximately 7 times more than is required to operate the system without reactor heating [15].

Table 1. Optimum operating parameters at different ambient temperatures [18].

\begin{tabular}{|c|c|c|c|c|c|}
\hline $\mathrm{T}$ & MLSS & SRT & $\tau$ & SGD & J \\
\hline${ }^{\circ} \mathrm{C}$ & $\mathrm{g} / 1$ & days & & $\mathrm{m}^{3} / \mathrm{m}^{2} \mathrm{~h}$ & $\mathrm{LMH}$ \\
\hline 15 & 15 & 41 & 3 & 0.10 & 16 \\
\hline 20 & 15 & 28 & 2.5 & 0.10 & 16 \\
\hline 25 & 10 & 19 & 2.5 & 0.10 & 23 \\
\hline 30 & 10 & 13 & 2 & 0.10 & 13 \\
\hline
\end{tabular}

where:

$\tau$ - sludge recycle ratio,

SGD - specific gas demand per membrane area

Other authors [16, 21] showed that COD concentrations in the feed wastewater had to be maintained at the level of at least 4-5 g/l to produce enough biogas to maintain a mesophilic process temperature.

Higher methane production in AnMBRs, if compared with conventional methods, is achieved by shorter HRTs used in membrane separation.

The AnMBR pilot studies conducted on municipal wastewater at different process temperatures showed that methane production decreased at lower temperatures [16]. Also a drop of methane recovery from the system was observed due to a higher solubility of methane at lower temperatures. The average methane production were $82.1 \mathrm{1} / \mathrm{kg}$ COD utilized (at $29.2^{\circ} \mathrm{C}$ ) and $15.4 \mathrm{l} / \mathrm{kg}$ COD utilized (at $17.1^{\circ} \mathrm{C}$ ); the respective recovery efficiencies were $71 \%$ and $9.1 \%$.

In other studies on treatment of municipal wastewater in the AnMBR at $25-30^{\circ} \mathrm{C} \mathrm{CH}_{4}$ production was $0.3 \mathrm{l} / \mathrm{g}$ COD utilized; about $67 \%$ of generated $\mathrm{CH}_{4}$ was dissolved in a liquid phase and lost in the permeate [8].

The a lab scale research conducted on municipal wastewater at $15^{\circ} \mathrm{C}$ showed that $40-50 \%$ of methane produced in the AnMBR process was dissolved in the permeate [17].

In early mentioned research with $2.2 \mathrm{~h}$ of $\mathrm{HRT}$, methane yield was $0.121 \mathrm{CH}_{4} / \mathrm{gCOD}_{\text {removed }}$ and $30 \%$ of total influent COD was used for methane conversion, $15 \%$ of COD for sulfate reduction, $10 \%$ for biomass growth and $10-20 \%$ of COD remained in the effluent [13].
Sulfate concentrations in wastewater can be another important factor influencing the amount of biogas produced [22]. Sulphates are always present in domestic and municipal wastewater but in different concentrations. In anaerobic processes, reduction of sulphates to sulphides takes place, which results in numerous technical and technological problems such as: (i) hydrogen sulphide is toxic to anaerobic microorganisms; (ii) produced biogas volume is lower because some of the influent COD (approx. $2 \mathrm{~g} \mathrm{COD} / \mathrm{g}$ $\left.\mathrm{SO}_{4}-\mathrm{S}\right)$ is consumed by sulphate-reducing microorganisms (SRB); (iii) poor biogas quality because some of the hydrogen sulphide ends up in the biogas.

The pilot study was carried out at 15 and $30^{\circ} \mathrm{C}$. The results were compared for two different sulphate concentrations in municipal wastewater: a high concentration of $57 \mathrm{mg} \mathrm{COD} / \mathrm{mg} \mathrm{S}-\mathrm{SO}_{4}$ and a low one of $5.7 \mathrm{mg} \mathrm{COD} / \mathrm{mg}$ of $\mathrm{S}^{-\mathrm{SO}_{4}}$ [23]. The research enabled to determine the optimum AnMBR operating parameters for these conditions. The results are presented in Table 2 .

Table 2. Optimum design values using the operating variables evaluated in this case study when treating (a) sulphate-rich municipal wastewater and (b) low-sulphate municipal wastewater [23].

\begin{tabular}{|c|c|c|}
\hline & $\begin{array}{c}\text { Winter } \\
\left(\mathrm{T}=15^{\circ} \mathrm{C}\right)\end{array}$ & $\begin{array}{c}\text { Summer } \\
\left(\mathrm{T}=30^{\circ} \mathrm{C}\right)\end{array}$ \\
\hline (a) & & \\
SRT (days) & 35 & 27 \\
HRT (hours) & 17 & 17 \\
MLSS (g/l) & 16 & 12 \\
TMP (bar) & 0.1 & 0.1 \\
\hline (b) & & 23 \\
SRT (days) & 17 & 17 \\
HRT (hours) & 15 & 12 \\
MLSS (g/l) & 0.1 & 0.1 \\
TMP (bar) & &
\end{tabular}

Then energy consumption was determined for the AnMBR operation presented in Table 2, as shown in Table 3 [23].

Table 3. Optimum cost and energy requirements of the proposed AnMBR WWTP when treating sulphate-rich and low sulphate municipal wastewater [23].

\begin{tabular}{|c|c|c|}
\hline & \multicolumn{2}{|c|}{$\begin{array}{c}\text { AnMBR energy requirements, } \\
\mathrm{kWh} \text { per } \mathrm{m}^{3}\end{array}$} \\
\hline & $\begin{array}{c}\text { Sulphate-rich } \\
\text { municipal } \\
\text { wastewater }\end{array}$ & $\begin{array}{c}\text { Low-sulphate } \\
\text { municipal } \\
\text { wastewater }\end{array}$ \\
\hline $\begin{array}{c}\text { No methane capture } \\
\text { Energy recovered from } \\
\text { methane (biogas } \\
\text { methane and methane } \\
\text { dissolved in the } \\
\text { effluent) }\end{array}$ & 0.22 & 0.21 \\
\hline
\end{tabular}

As it can be shown a MBR technology has the potential to be a net energy producer when treating low sulphate municipal wastewater. Table 3 shows that when methane is captured from biogas and effluent it is possible to obtain surplus energy that can be utilized 
and/or sold, giving a maximum theoretical energy production of $0,07 \mathrm{kWh}$ per $\mathrm{m}^{3}$.

The minimum energy consumption for systems with aerobic MBRs is approximately $0,34-0,55 \mathrm{kWh} / \mathrm{m}^{3}$ so the reactors are less efficient then AnMBRs; on the other hand AnMBRs do not assure a nutrient removal from wastewater [22, 23].

As far as energy saving is concerned, Wang et al. [24] suggest that dead-end filtration lead to low energy membrane operation in AnMBR systems.

\section{Membrane fouling}

In membrane fouling studies several parameters including operating conditions, feed/biomass characteristics and membrane characteristics has to be considered to have a major impact on membrane fouling [8]. Most critical for membrane fouling is probably quantity of suspended solids in raw wastewater $[25,26$, 27, 28].

Comparative research of Xiong et al. [29] on the membrane fouling mechanisms of aerobic (AeMBR) and anaerobic membrane bioreactors (AnMBR) showed faster membrane fouling in the AeMBR system. Also the fouling mechanisms in AeMBR and AnMBR systems are different, therefore fouling control strategies for these two systems should be different [29].

Fouling of AnMBR membranes is much more severe than in case of MBR membranes since AnMBRs operate at lower membrane permeate fluxes, and lower sludge filterabilities favour membrane fouling [5, 30, 31].

In the AnMBR processes micro- and ultrafiltration membranes are used [5]. There is a relationship between a fouling formation rate and a membrane pore size; larger pore sizes enable a higher permeate flow through membranes in time and then a more intense fouling.

Fouling intensity also depends on the process temperature and SRT [16]. Typically, fouling decreases with an increase of SRT and increases with temperature as a result of higher microbial activity. To reduce fouling on a membrane surface biogas recycle and permeate backwashing are used.

As it was shown in the research study membrane fouling was managed using biogas sparging and permeate backflushing [17]. Comparative fouling experiments suggested that the combination of this two fouling control measures was more effective than either fouling prevention method alone.

The researchers look for another fouling control measures. In Ontario a pilot study was conducted evaluating the fouling effect while adding to the AnMBR iron chloride at a $\mathrm{FeCl}_{3}$ dose of $26 \mathrm{mg} / 1[6,32]$. The research was carried out on municipal wastewater at $23^{\circ} \mathrm{C}$ using a hollow fiber membrane module (a pore size of $0.04 \mu \mathrm{m}$ ). It was found that $\mathrm{Fe}$ dosing resulted in higher MLSS concentrations and a thickener fouling layer on the membrane. However, the mixed liquor filterability was much better, as indicated by CST tests 1 $[6,32]$. The fouling layer was more porous and thicker and the deposition of protein and carbohydrate on the membrane surface was significantly less severe. The results suggested that the addition of $\mathrm{FeCl}_{3}$ could be an effective strategy to reduce membrane fouling. The process showed a higher sludge production (by 50\% ) and a better removal of COD (by about $17 \%$ ).

Another method, roughly tested, involves modification of biomass properties by use of flocculants in AnMBRs [33]. Results showed that the flocculant was able to substantially increase flux and a flux-increasing effect was observed for several weeks after a flocculant addition. A $100 \%$ increase in flux was observed at a flocculant dose of $300 \mathrm{mg} / 1$.

Interesting comparative research of a submerged granular anaerobic membrane bioreactor (SG-AnMBR) and external granular anaerobic membrane bioreactor (EG-AnMBR) suggests that this latest ones has got less fouling propensity [34]. However, a shortcoming of this research was a fact that only synthetic not actual municipal wastewater were used for laboratory experiments.

Similar comparative research of conventional granular anaerobic membrane bioreactor (CG-AnMBR) and a sponge assisted-granular anaerobic membrane bioreactor showed that the sponge addition could not only improve organics and nutrient removal, but also retain superior granular sludge properties and enhance methane yield $\left(156.3 \pm 5.8 \mathrm{ml} \mathrm{CH}\right.$ CHTP $\left._{4} / \mathrm{g}\right)$ [35]. Moreover, the sponge assisted-granular anaerobic membrane bioreactor showed longer operation time due to effective fouling mitigation $[35,36]$. The liquid chromatography organic carbon detection (LC-OCD) analysis suggested that sponge addition reduced the concentrations of biopolymers, low molecular weight neutrals and acids, and building blocks of the foulants. Also, fouling resistance analysis revealed that sponge addition could reduce the total foulin resistance by $50.7 \%$ due to decreasing both cake layer and pore logging resistance [35].

While comparing fouling formation on different membranes it was found that ceramic membranes had lower fouling propensity than polymeric membranes due to a weaker bonding between foulants and membranes $[8,37]$. In addition to their low fouling tendency, the membranes were resistant to more aggressive cleaning agents (used to shorten a cleaning time) due to their excellent stability and integrity

Promising technology is forward osmosis process (FO) which can simultaneously produce high quality effluent and preconcentrated wastewater for anaerobic treatment to enable energy and nutrients recovery [38]. Bench-scale research of an AnMBRs using external cross flow tubular membranes fed with synthetic and real municipal wastewater at 10 and $25^{\circ} \mathrm{C}$ and evaluated on the basis of energy demand and organic removal, showed energy demands of $0.05-0.13 \mathrm{kWh} / \mathrm{m}^{3}$ [39]. The $\mathrm{BOD}_{5}$ at the effluent was $10 \mathrm{mg} / 1$ at bioreactor hydraulic retention time (HRT) of 4.2-9.8 h, even at temperature as low as $10^{\circ} \mathrm{C}$. Moreover there is a potential for net neutral energy demand while efficient $\mathrm{BOD}_{5}$ and nutrients removal from municipal wastewater [39].

The performance of a pilot scale anaerobic membrane bioreactor (AnMBR), comprising an upflow anaerobic sludge blanket (UASB) reactor coupled to an 
external ultrafiltration membrane treating municipal wastewater at $18 \pm 2^{\circ} \mathrm{C}$, and operated over three years in stable conditions (with volumetric loading rate of between 2 and $2.5 \mathrm{~kg} \mathrm{tCOD} / \mathrm{m}^{3}$ d) showed COD removal efficiency of $87 \pm 1 \%$ at hydraulic retention time (HRT) of $7 \mathrm{~h}$, reaching effluent t COD concentrations of 100 $120 \mathrm{mg} / 1$ and $\mathrm{BOD}_{5}$ concentrations of $35-50 \mathrm{mg} \mathrm{O} / 1$ [40]. In the same time specific methane yield varied from 0.18 to $0.23 \mathrm{Nm}^{3} \mathrm{CH}_{4} / \mathrm{kg}$. The permeate flow rate, using cycles of $15 \mathrm{~s}$ backwash, $7.5 \mathrm{~min}$ filtration, and continuous biogas sparging $(40-60 \mathrm{~m} / \mathrm{h})$, with transmembrane pressure (TMP) values of $400-550$ mbar, ranged from 10 to $141 \cdot \mathrm{m}^{2} / \mathrm{h}$,

Comparative research of submerged and external anaerobic dynamic membrane bioreactors (AnDMBRs) showed some interesting results [41]. High COD removal efficiencies were obtained with both submerged and external AnDMBRs. However, to obtain an effective dynamic membrane layer enabling high quality permeate, longer time was required in the external AnDMBR system compared to the submerged one. Also, a difference in microbial community structure was identified: The number of archaeal types microbes decreased in the bulk sludge of the external AnDMBR. External sludge recirculation might have had a negative effect on the archaeal community in the bulk sludge of the external AnDMBR. However, the sludge recirculation in the external AnDMBR configuration led to a filtration at lower total filtration resistance and TMP in comparison to the submerged one [41]. Moreover, results showed that the submerged AnDMBR system can provide a shorter start-up period, slightly better permeate quality in terms of COD concentration, and higher biogas production in comparison to the external one in gas-lift mode.

Research with installed three-phase separator between bulk sludge and membrane module shoved decreased rate of membrane fouling, however such effect could be also due to long HRT and SRT [42]. The authors also suggested consumption of biofilm on the membrane heterotrophic bacteria Chloroflexi [42].

Interesting laboratory research on impact of diurnal flow variation and peak flow on anaerobic membrane bioreactor operation including membrane fouling control by gas sparking was investigated by Wang et al. [43]. One of their the important conclusions is suggestion to design AnMBR membrane surface area based on average flow rather than peak flow [43].

Membrane fouling rate depends on the properties of soluble microbial products (SMP), extracellular polymeric substances (EPS) and the organic loading rate (OLR) [44, 45]. Increase of OLR results in increase of production of specific EPS and macromolecules in the SMP and EPS fractions which stimulate flocullation and finally fouling cake formation [46]. Moreover, since the EPS is usually more viscoelastic and hydrophobic at a higher OLR, adhesion of fouling to the membrane increases drastically when OLR is higher than $1.4 \mathrm{~g}$ COD/1/d [44].

Interesting study of the AnMBR performance during long term (536 days) operations with a flux of $17 \mathrm{LMH}$ were carried out by Dong et al. [25]. Longest period of membrane recovery cleaning or replacement was 178 days and fouling rate was higher with cleaned membrane than new ones.

\section{Conclusions}

Application of AnMBRs complies with the idea of implementation of energy-saving and environmentally friendly technologies. At the current state of art, the AnMBR technology seems to be a promising alternative to the conventional anaerobic processes and aerobic MBRs. This is due to its ability to produce additional energy without incurring costs related to air supply, as it is in MBRs.

The use of membrane separation in anaerobic processes enabled to operate reactors while maintaining different operation conditions: a short HRT - relatively comparable to aerobic processes and a long SRT required for anaerobic organisms.

Opposite to high COD and TSS removals, the removal of total nitrogen (TN) or total phosphorus (TP) is usually negligible in the AnMBR systems. Partial nitritation/nitrification would be a promising solution for nutrient removal because ammonium could serve as the electron donor, and no additional carbon source/electron donor would be required in the process. Also, a forward osmosis process provides promising approach to resolve this challenge since FO process can almost totally reject nitrogen and phosphorus. Physical/chemical nutrient removal processes could be other solutions although they require significantly more energy than biological treatment [14].

\section{Acknowledgement}

Publication supported by the Polish Ministry of Science and Higher Education as a part of the program of activities disseminating science from the project „Organization of the First International Science Conference - Ecological and Environmental Engineering”, 26-29 June 2018, Kraków.

\section{References}

1. M. Bodzek, J. Bohdziewicz, K. Konieczny, Membrane Technology in Environmental Protection (Wydawnictwo Politechniki Śląskiej, Gliwice, 1997)

2. S. Judd, C. Judd, The MBR Book. Principles and Applications of Membrane Bioreactors for Water and Wastewater Treatment. Second Edition, (Elsevier 2011)

3. Membrane Bioreactors. WEF Manual and Practice No.36, (McGraw-Hill Education UK, 2011)

4. Z. Mucha, J. Mikosz, Environ. Technol. 37(19), $2516(2016)$

5. G. Skouteris, D. Hermosilla, P. López, C. Negro, A. Blanco, Chem. Eng. J., 198-199. 138 (2012)

6. Q. Dong, W. Parker, M. Dagnew, Water Res. 80, $281(2015)$ 
7. B. Bornare, U.S. Adhyapak, G.P. Minde, V. Kalyan Raman, V.S. Sapkal, R.S. Sapkal, Water Sci. Technol. 71, 1655 (2015)

8. X. Yue, Y. Keat, K. Koh, H.Y. Ng, Water Res. 86, $96(2015)$

9. Z. Huang, S.L. Ong, H.Y. Ng, Water Res. 45, 705 (2011)

10. E. Jeong, H.W. Kim, J.Y. Nam, H.S. Shin, Bioresour. Technol. 101, 7 (2010)

11. J. Kim, K. Kim, H. Ye, E. Lee, C. Shin, P.L. McCarty, J. Bae, Environ. Sci. Technol. 45, 576 (2011)

12. A.P. Trzcinski, D.C. Stuckey, Water Sci. Technol. 60, 1965 (2009)

13. X. Mei, Z. Wang, Y.Miao, Z. Wu, J. Water Reuse Desalin. 08, 1 (2018)

14. H. Lin, W. Peng, M. Zhang, J. Chen, H. Hong, Y. Zhang, Desalination 314, 169 (2013)

15. M. Saddoud, A. Ellouze, S. Dhouib, A. Sayadi, Environ. Technol. 27, 991 (2006)

16. J.B. Giménez, N. Martí, A. Robles, J. Ferrer, A. Seco, Water Sci. Technol. 69, 1581 (2014)

17. A.L. Smith, S.J. Skerlos, L. Raskin, Water Res. 47, 1655 (2013)

18. R. Pretel, B.D. Shoener, J. Ferrer, J.S. Guest, Water Res. 87, 531 (2015)

19. A. Kowalczyk-Juśko, B. Kościk, K. Jóźwiakowski, A. Marczuk, J. Zarajczyk, J. Kowalczuk, M. Szmigielski, A. Sagan, Przem. Chem. 94(10), 1838 (2015)

20. P.J. Van Zyl, M.C. Wentzel, G.A. Ekama, K.J. Riedel, Water Sci. Technol. 57, 291 (2008)

21. I. Martín, M. Pidou, A. Soares, S. Judd, B. Jefferson, Environ. Technol. 32, 921 (2011)

22. Z. Mucha, K. Kurbiel-Swatek, Przem. Chem. 95(2), $1000(2016)$

23. J. Ferrer, R. Pretel, F. Durán, J.B. Giménez, A. Robles, M.V. Ruano, J. Serralta, J. Ribes, A. Seco, Sep. Purif. Technol. 141, 378 (2015)

24. K.M. Wang, D. Cingolani, A.L. Eusebi, A. Soares, B. Jefferson, E.J. McAdam, J. Membr. Sci. 555, $125,(2018)$

25. Q. Dong,W. Parker, M. Dagnew, Chemosphere 144, $249,(2016)$

26. Q.B. Liao, T.K. Jeremy, M.B. David, Environ. Sci. Technol. 36, 489, (2006)
27. Z. Huang, S.L. Ong, H.Y. Ng, Water Res. 45, 705, (2011)

28. Z. Huang, S.L. Ong, H.Y. Ng, J. Biotechnol. 164, 82, (2013)

29. Y. Xiong, M. Harb, P.Y. Hong, Sep. Purif. Technol. 157, 192, (2016)

30. S.H. Baek, K.R. Pagilla, Water Environ. Res. 78, 133 (2006)

31. A. Spagni, S. Casu, N.A. Crispino, R. Farina, D. Mattioli, Desalination 250, 787 (2010)

32. Q. Dong, M. Dagnew, J. Cumin, W. Parker, Water Sci. Technol. 72, 1446 (2015)

33. H. Díaz, L. Azócar, A. Torres, S.I.C. Lopes, D. Jeison, Water Sci. Technol. 69, 2297 (2014)

34. C. Chen, W. Guo, H.H. Ngo, S.W. Chang, D.D. Nguyen, P.D. Nguyen, X.T. Bui, Y. Wu, Int. Biodeterior. Biodegr. 121, 131 (2017)

35. C. Chen, W.S. Guo, H.H. Ngo, Y. Liu, B. Du, Q. Wei, D. Wei, D.D. Nguyen, S.W. Chang, Renew. Energy, 111, 620 (2017)

36. Y. Liu, X. Zhang, H. Ngo, W. Guo, H. Wen, L. Deng, Y. Lia, J. Guo, Biores. Technol. 268, 658, (2018)

37. X. Yue, Y. Keat, K. Koh, H.Y. Ng, Water Sci. Technol. 72, 2301 (2015)

38. A.J. Ansari, F.I. Hai, W.E. Price, J.E. Drewes, L.D. Nghiem, J. Membr. Sci. 529, 195 (2017)

39. M.D. Seib, K.J. Berg, D.H. Zitomer, J. Membr. Sci. 514, 450 (2016)

40. J. Gouveia, F. Plaza, G. Garralon, F. Fdz-Polanco, M. Peńa, Bioresour. Technol. 185, 225 (2015)

41. M.E. Ersahin, Y. Tao, H. Ozgun, J.B. Gimenez, H. Spanjers, J.B. van Lier, J. Membr. Sci. 526, 387 (2017)

42. Y. Waktole Berkessa, B. Yan, T. Li, M. Tan, Z. She, V. Jegatheesan, H. Jiang, Y. Zhang, Biores. Technol. 250, 281, (2018)

43. K.M. Wang, B. Jefferson, A. Soares, E.J. McAdam, J. Membr. Sci. 564, 289, (2018)

44. R. Chen, Y. Nie, Y. Hu, R. Miao, T. Utashiro, Q. Li, M. Xu, Y.Y. Li, J. Membr. Sci. 531, 1, (2017)

45. F.G. Meng, S.R. Chae, A. Drews, M. Kraume, H.S. Shin, F.L. Yang, Water Res. 43, 1489, (2009)

46. M.F. Dignac, P. Ginestet, D. Rybacki, A. Bruchet, V. Urbain, P. Scribe, Water Res. 34, 4185, (2000) 